\title{
Exploring the engagement of Pacific island judges with the Convention on the Rights of the Child
}

Sue Farran*

\begin{abstract}
This article considers the extent to which judges in cases involving children in the island states of the Pacific, act consistently with, or are influenced by, the United Nations Convention on the Rights of the Child (UNCRC). All Pacific island states have ratified the UNCRC but giving effect to children's rights faces challenges not least for judges. Drawing on the case-law of the region this article presents a quantitative and qualitative review of judicial engagement with the Convention, revealing that there are examples of good practice which could be shared, but also continuing difficulties which need to be met.
\end{abstract}

\section{Key words}

Children, Rights, Judges, Pacific island states

* Sue Farran is a Reader in the School of Law, Newcastle University, Newcastle upon Tyne, England.

Acknowledgments: The author would like to acknowledge the helpful and detailed feedback from anonymous reviewers and from Professor John Tobin and Professor Kathryn Hollingsworth 


\section{Exploring the engagement of Pacific island judges with the Convention on the Rights of the Child}

\section{Introduction}

In March 2020 the UN Committee on the Rights of the Child held an outreach session in Apia, Samoa. Although not all Pacific islands were represented, the chair of the Committee, Luis Pedernera stated, 'By holding a session in the Pacific, we wanted to draw the world's attention to the pressing issues affecting the enjoyment of children's rights in the region' (OHCRH 2020). While there are many issues that affect these rights, this article focusses on the extent to which Pacific island judges take the United Nations Convention on the Rights of the Child (UNCRC) into account in cases involving children.

This article is inspired by the Rewriting Children's Rights' Judgments' project coordinated by Helen Stalford, Kathryn Hollingsworth and Stephen Gilmore in the period 2016-2017. Although a great many cases from different countries and legal systems were considered for the original project, none were drawn from Pacific island states. This article does not seek to rewrite any judgments. Instead it focusses on how judges in the region currently consider children's rights in cases in which children are central.

Stalford et al suggest that 'explicit reference within judgments to the $\mathrm{CRC}$ is a key indicator of judicial attempts to recognise children as rights-holders and to engage with the interpretation of those rights' $(2017,54)$. Table One, which draws on the research undertaken for this article, demonstrates that increasingly Pacific judges are referencing the UNCRC.

Table One: Annual Record of Higher Court Cases referring to UNCRC 2010-2019 


\begin{tabular}{|l|l|}
\hline Year & Number of Cases \\
\hline 2019 & 8 \\
\hline 2018 & 10 \\
\hline 2017 & 9 \\
\hline 2016 & 10 \\
\hline 2015 & 19 \\
\hline 2014 & 6 \\
\hline 2013 & 5 \\
\hline 2012 & 5 \\
\hline 2011 & 4 \\
\hline 2010 & 6 \\
\hline
\end{tabular}

However, if children's rights are to take centre stage in cases involving them, ${ }^{1}$ then judicial engagement has to go beyond merely acknowledging the existence of the UNCRC. As Justice Nelson has said in Samoa 'more than lip service must be paid to that Convention'. ${ }^{2}$

In order to test whether this admonition is being observed, the research identified one hundred cases from the higher courts of Pacific island jurisdictions, in which the UNCRC was mentioned. ${ }^{3}$ The two main categories in which the articles of the UNCRC are cited most often are: criminal cases in which children are either defendants or victims; and adoption or

${ }^{1}$ Tobin's point that cases may involve indirectly affect children even if they are not central to it, is noted, but the methodology excludes such cases.

${ }^{2}$ Police v Amate [2011] WSSC 148. Paragraphs unnumbered.

${ }^{3}$ The jurisdictions considered are states coming under the influence of the common law. 
'custody' cases. ${ }^{4}$ Of the one hundred cases identified, ${ }^{5}$ sixteen are critically considered below, to determine whether, and to what extent, there is 'substantive treatment of children's rights' (Tobin 2009, 582). ${ }^{6}$

By this Tobin means decisions which are consistent with an approach which involves consideration of '(a) the wishes of the child; (b) the relevance of any other rights under the CRC; (c) the particular circumstances of the child; and (d) any available empirical evidence which may be of relevance' (Tobin 2009, 592).

Although many cases fall short of meeting all these features, those that were considered show that, as in Tobin's model, there is a spectrum of engagement with children's rights, ranging from robust judicial activism, in which at least some of Tobin's characteristics feature, to cases where the child's rights are invisible. What also emerges is that the Pacific judicial responses are very much shaped by the legal, social and cultural context of these states, which can both facilitate and frustrate furthering children's rights through the courts.

The article starts by setting out the context of children's rights in the Pacific. It then explains the methodology used to select the cases for this paper, before turning to the cases themselves. Finally, it considers the challenges confronting Pacific island judges in engaging

\footnotetext{
${ }^{4}$ The term 'custody' tends to be used in the Pacific. See e.g. Conway v Samuel [2020] PGNC 108, Nakamura v Dalley [2018] VUSC 134, Family Law Code 2007 (Niue).

${ }^{5}$ This does not take into account reference to the UNCRC by lower courts or specialist courts such as the Youth Court in Samoa, or Family Division of the High Court in Fiji.

6 Tobin (2009) presents a spectrum of engagement which includes: invisible, incidental, selective, rhetorical, superficial and substantive.
} 
with the UNCRC and concludes by suggesting how current and future initiatives could address some of these.

\section{The context of children's rights in the Pacific}

Along with nearly all other sovereign states, Pacific island states have endorsed the idea of children's rights through ratification of the UNCRC. In most of these states, however, the UNCRC has not been formally incorporated into domestic law (Corrin 2016:265). ${ }^{7}$

However, as with other human rights instruments, it may apply either through constitutional recognition of the general applicability of international law and/or through positive judicial referencing (Tamata 2009).

State reporting on the UNCRC has been patchy and often overdue (Baird 2015), but all Pacific UN member states have undergone Universal Periodic Review (UPR), now in its third cycle (2017-2022). ${ }^{8}$ UPR reports cover a wide range of human rights instruments including observations on the status of children's rights. After the first round of the UPR the Secretariat of the Pacific Community and the Regional Rights Resources Team produced a toolkit. ${ }^{9}$ This

\footnotetext{
${ }^{7}$ Exceptionally Vanuatu has incorporated the UNCRC via the Convention on the Rights of the Child (Ratification) Act 1992.

${ }^{8}$ The 12 Pacific Island states which are members of the UN are the Federated States of Micronesia, Fiji, Kiribati, Marshall Islands, Nauru, Palau, Papua New Guinea, Solomon Islands, Samoa, Tonga, Tuvalu and Vanuatu.

9 'Pacific Island States and the Universal Periodic Review: A toolkit for Pacific Island States to measure progress and compliance against the Universal Periodic Review Recommendations' SPC and RRT 2012. Available at
} 
included thematic tables identifying key concerns and making recommendations for each country. Among these recommendations were the 'promotion and education on human rights for communities, law enforcement agencies, government officials and legal professionals' (Table 4). Recommended country compliance indicators included mainstreaming human rights education for lawyers and justice officials and promoting 'features of the legal framework which are consistent with international obligations'. ${ }^{10}$

The engagement of 'justice officials' is significant, because a key point of the Children's Rights' Judgments' project is that the judiciary play a central role in developing approaches which give real-life effect to the values espoused by the UNCRC. As Tobin has explained, 'the role of the judiciary ... provides a very strong indication of the extent to which the relevant international norms have been internalised and brought to life within the domestic legal system' (Tobin, 2009, 580).

Throughout the UNCRC there is reference to law, laws, legislation and legislative bodies, legal guardians and those legally responsible for a child, judicial review and judicial proceedings and courts of law. ${ }^{11}$ Although as an international convention the UNCRC is

https://rrrt.spc.int/sites/default/files/resourcing/2019-

01/Pacific_Island_States_and_the_Universal_Periodic_Review.pdf.

${ }^{10}$ See e.g. recommendations made (above) for Tuvalu 46; Vanuatu 51 and 59; Fiji 71.

${ }^{11}$ The Preamble refers to 'appropriate legal protection', the Declaration on Social and Legal Principles Relating to the Protection and Welfare of the Child and the UN Standard Minimum Rules for the Administration of Juvenile Justice. The text of the Convention refers to the terms mentioned in Articles: 2(1) and (2); 3(1) and (2); 4; 5; 7(2); 8(1); 9(1); 10(2); 12(2); 13(2); 14 (2) and (3); $15(2) ; 16(2) ; 18$ (1) and (2); 19 (1) and (2); 20 (2); 21(a); $26(1) ; 32$ (2); 33; 37 (b) and (d); 38 (1) and (4); 40 (1), (2) and (3) and 41. 
primarily focussed on the obligations of states, the scope of Article 3 specifically encompasses 'all actions concerning children' and (as indicated above) 'courts of law' (Farran 2012). The role and responsibilities of individuals is also acknowledged, including parents, legal guardians 'or other individuals legally responsible for him or her' (referring to the child). The jurisdiction and operation of courts is framed by the state laws that create them and judges can only act within the bounds of the substantive and procedural laws. Their ability to engage with the UNCRC may, therefore, be constrained by the state. Nevertheless, there may be scope for judges to adopt a rights-based approach within those constraints. This article considers if and how they do so by considering some of the reported cases of the region. .

\section{Methodology}

\subsection{Selection of cases}

In selecting these cases this paper focusses on those in which there is reference to the UNCRC. A breakdown of the number of cases in which the specific articles are referred to, is given in Table Two. It is acknowledged that there may be other cases where the principles informing the UNCRC were considered even if no direct reference to it was made. These lie outside the scope of this article.

Table Two: UNCRC articles, referenced in cases.

\begin{tabular}{|l|l|}
\hline Article $^{12}$ & Frequency of reference \\
\hline Preamble & 3 \\
\hline 1 & 2 \\
\hline 2 & 3 \\
\hline
\end{tabular}

${ }^{12}$ Articles to which no reference was found are excluded. 


\begin{tabular}{|l|l|}
\hline 3 & 13 \\
\hline 6 & 4 \\
\hline 7 & 1 \\
\hline 8 & 1 \\
\hline 9 & 3 \\
\hline 16 & 3 \\
\hline 18 & 2 \\
\hline 19 & 10 \\
\hline 20 & 3 \\
\hline 21 & 12 \\
\hline 26 & 2 \\
\hline 28 & 2 \\
\hline 34 & 9 \\
\hline 37 & 29 \\
\hline 39 & 1 \\
\hline 40 & 11 \\
\hline Non-specific general reference to the & 40 \\
\hline
\end{tabular}

Some cases referred to more than one article, others to just one. Where the UNCRC was referred to in general, rather than specific articles, this may have been to dismiss it - for example, in asylum cases involving Nauru, or where it was ruled inapplicable because of the facts, or not considered further because domestic legislation has given effect to its provisions - for example, the Criminal Code (Sexual Offences and Crimes Against Children) Act 2002 (Papua New Guinea), the Lukautim Pikinini Act (Papua New Guinea) and the Child 
Protections and Welfare Act 2016 (Nauru). In some cases, the UNCRC was mentioned 'in passing' without any further detailed engagement with its articles.

Cases were located on the electronic data base Paclii.org, ${ }^{13}$ using the search term 'Convention on the Rights of the Child'. ${ }^{14}$ As all Pacific island countries have completed the first (2008-2011) and second cycle of the Universal Periodic Review (2012-2016), the cases selected are those from 2008 onwards. ${ }^{15}$

\subsection{The courts}

The cases considered are taken from the higher courts of the region (set out in Table Three), ${ }^{16}$ which are staffed by professional judges. ${ }^{17}$ The nomenclature of these courts varies slightly across the jurisdictions. For some countries the final court of appeal remains the Judicial Committee of the Privy Council in England, and in Nauru appeals from the Supreme Court of Nauru are to the Supreme Court of New South Wales - sitting as a Court of Appeal, and to

\footnotetext{
${ }^{13}$ Very few cases in the Pacific region are found in official reports. The cases on Paclii are therefore 'unreported' cases and may not reflect all the cases heard in any one year or from any one jurisdiction as submission to Paclii is dependent on the country of jurisdiction. .

${ }^{14}$ Other search terms such as 'children's rights', 'human rights of children', 'declaration of children's rights', either produced no data or data that overlapped with the selected search term.

${ }^{15}$ All the Pacific Island countries signed up to the UNCRC in the 1990s and therefore assumed the Convention's obligations some time before the UPR.

${ }^{16}$ These may be appeal courts and/or courts of original jurisdiction.

${ }^{17}$ The Paclii reference to cases indicates the court: for example, FJSC is Fiji Supreme Court.
} 
the High Court of Australia (Dale 2007). ${ }^{18}$ The rule of precedent applies in these jurisdictions and so the decisions of these courts are influential in shaping the development of the law.

Table Three: The higher courts in Pacific Island States

\begin{tabular}{|c|c|c|c|}
\hline Cook Islands & High Court & Court of Appeal & UK Privy Council \\
\hline $\begin{array}{l}\text { Federated States of } \\
\text { Micronesia }\end{array}$ & $\begin{array}{l}\text { State Courts of } \\
\text { Chuuk, Kosrae, } \\
\text { Pohnpei and Yap }\end{array}$ & FSM Supreme Court & \\
\hline Fiji & Court of Appeal & Supreme Court & \\
\hline Kiribati & High Court & Court of Appeal & \\
\hline Marshall Islands & High Court & Supreme Court & \\
\hline Nauru & Supreme Court & Court of Appeal & $\begin{array}{l}\text { Supreme Court of } \\
\text { NSW } \\
\text { High Court of } \\
\text { Australia }\end{array}$ \\
\hline Niue & High Court & Court of Appeal & UK Privy Council \\
\hline Papua New Guinea & National Court & Supreme Court & \\
\hline Samoa & Supreme Court & Court of Appeal & \\
\hline Solomon Islands & High Court & Court of Appeal & \\
\hline Tonga & Supreme Court & Court of Appeal & UK Privy Council \\
\hline Tuvalu & High Court & Court of Appeal & UK Privy Council \\
\hline Vanuatu & Supreme Court & Court of Appeal & \\
\hline
\end{tabular}

${ }^{18}$ Cases decided by these external courts were not included. 


\subsection{The Judges}

The appointment of judges is primarily governed by the Constitutions of Pacific Island countries. While an increasing number of judges are indigenous, there are also nonindigenous judges, especially on final courts of appeal (Paterson 2009). Described as 'cultural outsiders' (Baird 2014), ex-patriate judges may have to achieve a balance between detachment and judicial independence, and acknowledgment of local circumstances. The two may not be compatible (Dziedic 2017). As Pulea states, 'detachment could very well breed an inability to understand the local conditions as values, customs and culture differ from society to society' (Pulea 1980: 9). On the other hand some ex-patriate judges have extensive experience of working in the Pacific and/or outside their jurisdictions of nationality. Because most ex-patriate judges are appointed on short-term contracts, their influence on the development of the law may be limited. Research published by Ingram in 2011, found that short-term contracts were common in Cook Islands, Marshall Islands, Kiribati, Nauru, Papua New Guinea, Tonga and Vanuatu (Ingram 2011: 376). Jowitt (2015), however, has suggested that short-term contracts may encourage more judicial activism with judges eager to 'make a mark'.

Indigenous judges may serve for life (for example, in Tonga), or until retirement age (for example, in Cook Islands, Marshall Islands, Nauru, Samoa, Solomon Islands and Vanuatu). The number of high court judges is limited, and many cases are heard by a single judge. His/her views, therefore, may be influential for some time. ${ }^{19}$ The identity, and where available nationality, of the judges involved in the sixteen cases considered in detail in this article is indicated in footnotes.

${ }^{19}$ A single judgment is given. There are no dissenting opinions. 
A review of these selected cases, however, presents no conclusive evidence that indigenous or non-indigenous judges were more or less likely to adopt a child's rights' approach (see Table Four). ${ }^{20}$

Table Four: Judicial engagement with the UNCRC

\begin{tabular}{|l|l|l|}
\hline Engagement with & Indigenous $^{21}$ & Non-Indigenous \\
UNCRC & & \\
\hline Positive & 6 & 5 \\
\hline Negative & 3 & 2 \\
\hline
\end{tabular}

\section{The Children's Rights' case law}

Drawing on the data set out in Table Two, the judgments considered below focus on three categories of cases: criminal cases in which children are victims or defendants; family law cases, notably issues of custody of children, and applications for adoption; and cases in which the rights of children have to be considered in the context of customary practices which are taken into account by the courts. This third category of cases (which often overlaps with the first) has been selected because these cases present particular challenges in determining how to address children's rights in plural legal systems.

\subsection{The challenges of legal pluralism}

${ }^{20}$ Further research into judges' background and training might be enlightening but is beyond the scope of this article.

21 'Indigenous' includes all Pacific Islander judges even if they are sitting in courts outside their country of origin. 
In the Pacific, judges dealing with cases involving children cannot avoid the challenges presented by plural legal systems in which custom and customary law play an important role. In a number of constitutions custom is formally recognised as a source of law although it is not always clear what weight should be attached to it compared to other sources of law, or indeed, if it is distinct from state law (Corrin 2009). In particular there is potential for conflict between custom and non-discrimination based on sex (Jessop 2010; Brown and Corrin Care 1998), including, for the purposes of this article, customs which impact on the girl-child. At the same time however, it should be pointed out that the UNCRC specifically acknowledges custom and/or traditions. The concluding paragraph of the Preamble, for example, states that due account should be taken 'of the importance of the traditions and cultural values of each people for the protection and harmonious development of the child'. Article 5 exhorts states to 'respect the responsibilities, rights and duties of parents or, where applicable, the members of the extended family or community as provided for by local custom ....', while Article 29(1)(c), referring to the right to education, states that this should also be directed to 'The development of respect for the child's parents, his or her own cultural identity, language, values ...' Article 30, referring to children who are indigenous (or a member of a minority), states that a child has a right 'to enjoy his or her own culture'. The UNCRC also frequently uses the phrase in accordance with/in conformity with 'the law', so that where custom or customary law is part of 'the law' this may be interpreted as being in conformity/accordance with custom or customary law and practices.

This plural legal context informs the jurisprudence of Pacific island courts. Often judges have to negotiate a difficult pathway between judgments that reflect contemporary thinking about children's rights and give effect to the international obligations assumed by Pacific island states, and decisions which will be acceptable and effective within the social and cultural contexts in which they operate. 


\subsection{Children's rights and the criminal law}

As is evident from Table Two, Articles 19, 34, 37 and 40 are among the most frequently cited in the cases identified. This may be because serious criminal cases are more likely to come before the higher courts, either as courts of first instance or on appeal. What is noticeable in these cases is that judges engage with Articles 37 and 40 in respect of child offenders, and with Articles 19 and 34 in respect of adults committing crimes against children. In both respects the UNCRC focus tends to be on offenders rather than victims, although there are exceptions.

\subsubsection{Children as victims}

Unfortunately, children are victims of exploitation, neglect, and violence, including sexual violence, sometimes perpetrated by strangers but often by family members or those entrusted with their care (UNICEF 2017).

One of the first hurdles of the court process is for a child victim to get his or her story heard. This is particularly problematic where rules of evidence may require corroboration. This was considered in Kumar v State [2016] FJSC 44, ${ }^{22}$ a Fijian case involving an appeal against conviction for the rape of a seven-year-old girl. The legal question was whether the child's evidence needed to be corroborated. This is a statutory requirement for unsworn evidence given by children, ${ }^{23}$ which could only be circumvented if that law was found to be

\footnotetext{
${ }^{22}$ Justice Sathayaa Hettige (Sri Lanka), Justice Suresh Chandra (Sri Lanka) and Justice Brian Keith (British) who gave the judgment.

${ }^{23}$ Juveniles Act Section 10(1), (Cap 56) 1974. Reference was also made to the common law requirement that a judge should warn assessors of the danger of convicting a defendant on the uncorroborated evidence of a child, Kumar v State [2016] FJSC 44 [37]. The need for
} 
unconstitutional. ${ }^{24}$ In this case the child had given sworn evidence but it was unclear if the trial judge had established whether she understood the significance of the oath. The Supreme Court recognised that in sexual assaults involving children there may well be no corroborating witnesses and that these assaults could therefore go unprosecuted. To require such corroboration could mean that primary importance was given to the defendant's procedural rights, whereas, if section 41(1)(d) of the Constitution was to be effective, the best interests of the child should be of primary importance. ${ }^{25}$ Consequently, requiring the corroboration of a child's evidence, whether sworn or unsworn was unconstitutional. In order to ensure the defendant's rights to a fair trial, a judge could warn assessors about accepting the evidence (of a child or an adult) if the circumstances required it. Failure to warn the child of the importance of the oath therefore became irrelevant. The Supreme Court referred with approval to Justice Gounder's judgment in the Court of Appeal in which he stated that 'this interpretation is consistent with the Convention on the Rights of the Child ... The Convention allows for judicial involvement to carry out the protective measures for children' ${ }^{26}$ and dismissed the appeal. As a Supreme Court decision, the case sets a precedent in Fiji, particularly in giving effect to Article 19 and 34 of the Convention. In other jurisdictions,

corroboration in cases of adult sexual assault had been abolished under the Criminal Procedure Decree in 2009.

${ }^{24}$ In the Court of Appeal incompatibility had been found on the grounds of discrimination based on age under section 26(7) of the Constitution - Kumar v State [2015] FJCA 32. ${ }^{25}$ Section 41(1)(d) states that 'Every child has the right ...to be protected from abuse, neglect, harmful cultural practices, any form of violence, inhumane treatment and punishment, and hazardous or exploitative labour '

${ }^{26}$ Kumar v State [2015] FJCA 32, [34] 
judges might have scope to examine the rule of corroboration but may lack constitutional tools to achieve the same outcome.

If the accused pleads not guilty, the child victim will usually have to appear in court and be subject to cross examination. The negative impact on the child victim of this experience, seems to be under-considered in the region, although conversely, saving a child from the trauma of appearing in court as a witness may operate in the accused's favour. ${ }^{27}$ For example, in the Solomon Islands case Regina $v$ Kingsley [2015] SBHC 57, ${ }^{28}$ the victim of attempted rape was a 7 -year-old child, and the offender a young man of 20 , who entered a not-guilty plea. The child had already been subject to an intensive and intrusive physical examination. ${ }^{29}$ In determining sentence the child was visible as a member of a class requiring special protection: 'The victim is a child. Whilst children are protected under our Penal Code in terms of sexual offences, they are also protected under the Convention on the Rights of the Child' (para 4). The court also noted that 'Sexual offences against girls and women are prevalent in this jurisdiction. They are increasing' (para 7), ${ }^{30}$ The court acknowledged the physical and psychological trauma to the individual victim, 'as manifested by her demeanour during the trial' (para 5). It did not, however adopt a substantive child rights approach

${ }^{27}$ This was noted positively in Public Prosecutor v Malkorkor [2015] VUSC 147 [13] and Republic v Tannang [2019] NRSC 25 [13(iv)].

${ }^{28}$ Justice Mwanesalua (Deputy Chief Justice) (Solomon Islander)

${ }^{29}$ See Regina v Kingsley [2015] SBHC 51.

${ }^{30}$ Similar sentiments were expressed in the Samoan case of Police v JI [2018] WSCC 50 : 'The Samoan courts have also long recognized the prevalence of sexual offending in the community ...'(para 20). See also: Republic of Nauru v Aku [2018] NRSC 5 [24]; State v Kelerea (No.2) [2014] PGNC 158.[37] and [38]. 
because it was clear from the facts that this very young victim had been brought into court and cross-examined. Not only is this of concern in terms of the best interests of the child but also her right to privacy and her right to be treated with dignity and due appreciation for her age. Rather than focussing on the specific child, the court raised the level of sentencing to address the prevalence of sexual offending. The child here was therefore incidental to, although illustrative of, a wider problem.

Sentencing confers a degree of discretion on the courts and it would be possible to take into account the extent to which a child's rights have been infringed. A good example can be found in the Samoan case of Police $v J I$ [2018] WSSC 50. ${ }^{31}$ In this case the court very clearly bore in mind the UNCRC especially Article 19(1) imposing a duty on the state to protect children from all forms of abuse, and Article 34, which imposes a particular duty on states to protect children from all forms of sexual exploitation and abuse. The victim, a thirteen-year old child at the time of the first offending, had been repeatedly sexually abused by her father. In this case there was a victim report to which the court referred, highlighting the impact of the assault on this particular child. Although the UNCRC has not been incorporated into domestic law the court cited with approval cases that justified referring to it. ${ }^{32}$ It also addressed concerns that are sometimes raised about 'western-style' laws by linking the principles underpinning the UNCRC with the Fa' ' Samoa, ${ }^{33}$ notably 'the community's strong Christian values, Samoan culture and the role of a father in the Samoan family unit' (para 20). Emphasising the culturally appropriate role of family members to emphasise the gravity of the offence, is found in a number of other cases where the sexual

\footnotetext{
${ }^{31}$ Justice Leiataualesa Daryl Michael Clarke (Samoan).

${ }^{32}$ E.g. Police v Faiga [2008] WSSC 96.

${ }^{33}$ The Samoan culture or 'way of life'.
} 
assault or rape of a child has been perpetrated by a relative. ${ }^{34}$ This normative linking of modern (introduced) law with traditional social ordering offers a promising way for the courts to adopt an acceptable substantive approach to children's rights.

While sexual abuse cases cause particular human rights concerns in the region, children are subject to other forms of degrading treatment. The Fijian case of Chief Executive Officer for Education v Gibbons [2013] FJCA 98, ${ }^{35}$ which was an appeal against aggravated damages, is an example. Here there is extensive reference to the child's rights established in Articles 16 (1) and (2), 28(2), 25 and 37 of the UNCRC, in particular the subjection of the 10-year-old child to cruel and degrading treatment and interference with his personal privacy. In 2005 the victim had been punished by being ordered to pull down his pants in front of the class. The class teacher had then instructed another pupil to pull down the child's boxer shorts, leaving the victim standing in his shirt and underwear. The accused: the class teacher, the head teacher and the Chief Executive Officer of Education and the Ministry of Education, argued in their defence that the UNCRC had not been incorporated into the national law of Fiji. As in the above Samoan case of $J I$ this was not seen as an obstacle. Fiji had ratified the UNCRC, it had been applied in many cases, and indeed Fiji had incorporated a number of principles of the UNCRC into various domestic laws. ${ }^{36}$

In this case no expert witness was called in respect of the trauma suffered by the child and there was a six-year gap between the complaint and the court of first instance trial in 2011. Nevertheless, the enabling environment established by precedent and legislation meant that

\footnotetext{
${ }^{34}$ See e.g. Police v S AN [2009] WSSC 56; $R$ v Manele [2020] SBHC 37.

${ }^{35}$ Justice Chandra (Sri Lanka), Justice Basnayake (Sri Lankan) and Justice Mutunayagam.

${ }^{36}$ E.g. the Domestic Violence Decree 2009, the Family Law Act 2003 and the Human Rights Commission Decree No 112009.
} 
the court could adopt a substantive approach to this child's rights. In particular the court 'heard' the child. Referring to the judgment of the court of first instance, the Appeal Court accepted that 'The child said that the incident traumatized him and caused injury to his feelings and dignity' (para 21), and that at the time of the incident 'He had sufficient understanding to have feelings of fear, anger, happiness, sadness, embarrassment, humiliation and likewise'(para 21). Even without expert evidence it was accepted that 'this child's suffering was not for a day or two. It is a lifetime suffering and he would be reminded of the incident every time he meets his ex-school colleagues and seniors' (para 13). The appeal against aggravated damages for battery was rejected. The case is significant not only in terms of the centrality of the child but also the clear recognition of the current and future challenges this child faced.

\subsubsection{Children as Defendants}

Progress is gradually being made in the Pacific region to develop distinct procedural safeguards for child offenders. Within this enabling legal environment there is a growing body of case law which has given substantive effect to the procedural rights of the child established in the UNCRC. These include the requirement that he or she has the right to have a parent or guardian present at any police interview following an arrest or detention in connection with a suspected criminal offence; ${ }^{37}$ and that admissions made by the child where there was no parent or guardian present are inadmissible as evidence. ${ }^{38}$ The rights of an

${ }^{37}$ See e.g. Simona $v$ The Crown [2002] TVHC 1 in Tuvalu and Police v Faiga [2008] WSSC 96.

${ }^{38}$ In the Samoan case of Police v Vailopa [2009] WSSC 69, specific reference was made to the Preamble of the UNCRC and Articles 37(b),(c)and (d) and article 40(1) and (2)(b)(ii). Justice Nelson (Samoan). 
accused child to due process have also received attention where there have been unacceptable delays to prosecution. In $R v$ Setaga [2008] TVHC $13,{ }^{39}$ a case from Tuvalu, the accused was 13-years-old and the victim 7-years-old. The charge was 'defilement of a child'. The conduct giving rise to the charge had taken place in 2003. The accused had not been interviewed by the police until 2004 and not charged until 2008. The Tuvalu Constitution enshrines the right to a fair trial (section 22(2)) but the court also referred to Article 40(2)(b) of the UNCRC referring to reasonableness of delay, acknowledging that 'Where a child was accused there was a far greater sense of immediacy'. ${ }^{40}$ To give practical effect to the UNCRC the court used section 17 of the Interpretation and General Provisions Act (Cap 1.04 Tuvalu), which supports the construction of written law in line with international obligations, to order a stay of proceedings.

In the field of sentencing Articles 37 and 40 of the UNCRC appear to be increasingly cited to support non-custodial sentences on young offenders, ${ }^{41}$ even where the crimes committed are serious, especially where other factors may already incline the judge to this course of action. ${ }^{42}$ An example can be found in the Samoan case of Police v L.S. [2017] WSSC 96.

\footnotetext{
${ }^{39}$ Chief Justice Ward (British).

${ }^{40}$ Paragraph unnumbered.

${ }^{41}$ Legal reform also takes these provisions into account, see e.g. in Nauru, the Child
} Protection and Welfare Act 2016, section 48.

${ }^{42}$ See e.g. Public Prosecutor v Molsir [2017] VUSC 74. Other factors may include a guilty plea, evidence of remorse, status as a first-time offender, and apology including customary apology/compensation. See Police v Toma [2015] WSSC 65, in which the court briefly notes that 'The victim report shows that the victim has not forgotten the incident but is trying to forget' [7] and dedicates the rest of its attention to mitigation of sentence. 
Counsel for the 14-year old accused drew the attention of the court to the principles of justice and sentencing in the UNCRC. The court accepted that Samoa's Young Offenders Act 2007, was intended to be based on the principles of the UNCRC but went further. Drawing on the New Zealand case of Churchward $v R$ [2011] NZCA 511, Justice Tuatagaloa accepted and applied the following considerations in determining sentence:

(i) There are neurological differences between young people and adults ... which makes a young person more impressionable and impulsive

(ii) It is recognised that longer prison sentences tend to have a greater negative impact on young people (the maximum sentence for manslaughter in Samoa is life imprisonment)

(iii) Young people are generally more able to be rehabilitated and reintegrated into the community

(iv) For young people, offending is often a short-lived thing with offenders growing out of a tendency to offend

(v) Criminal convictions when a person is young may have a disproportionately greater effect on the person's future prospects. (para 20)

This demonstrated a clear awareness of some of the debates surrounding juvenile offenders and the principles of the UNCRC. The judge also adopted a very traditional approach, which was to consider the accused's contribution to society and conformity with expected social values. Toma was a college student, supported by his parents, who was involved in helping with Sunday school at his village church, church youth and the church choir. The village representative and the pastor provided testimonials which indicated that he was a 'good leader with a promising future'(para 7). This combination of contemporary understandings of juvenile offenders and traditional values pertaining to the individual within the community, resulted in two year's supervision rather than 18 months' imprisonment. 
In giving effect to the UNCRC courts have even extended the principles of Articles 37 and 40 to offenders who are no longer children, as illustrated by the case of Public Prosecutor $v$ Malkorkor [2015] VUSC $147 .{ }^{43}$ This was a gang rape case. Rape normally carries a custodial sentence. All of the accused were young men, but apart from one whose age was uncertain, they were over eighteen, and therefore not children under the UNCRC. In deciding on a suspended sentence for all the accused, the court referred specifically to Article 37 and 40. This, as pointed out by the judge, is a particular consideration where there are no dedicated facilities for young offenders in which they can be held separately from adult offenders. ${ }^{44}$ Here the UNCRC and pragmatism complement each other.

Conversely, judges may use the age cut-off of 18 to avoid the UNCRC, as occurred in the Kiribati case of Attorney-General v Benna [2019] KICA 11. Here the offenders were children at the time the offence of rape was committed, but adults by the time of trial. In the lower court a suspended sentence was imposed, favouring a UNCRC compliant approach. On appeal by the prosecutor, this was increased to a term of imprisonment for both offenders. The court held that 'the appropriate sentencing methodology was to treat each of the offenders as if they were adults, and then to reduce the sentence by reference to mitigating factors, including youth. ${ }^{45}$ While engagement with the UNCRC here was not substantive, sentencing guidelines may allow judges to engage with children's rights in borderline situations.

\footnotetext{
${ }^{43}$ Justice Fatiaki (Rotuma, Fiji).

${ }^{44}$ Public Prosecutor v Malkorkor [2015] VUSC 147 [21]. A similar consideration applied in Republic v AB [2019] KIHC 30.

${ }^{45}$ Attorney-General v Benna [2019] KICA 11 [49]. Justice Blanchard (New Zealand).
} 


\subsection{Family law cases}

Articles 3 and 21 are frequently referenced in cases in which the child is the central focus, particularly in cases concerning the custody children or those involving formal adoption.

\subsubsection{Care and protection cases}

Two cases: Dalley v Dalley [2016] VUSC 91 and Nakamura v Dalley [2018] VUSC 134, which involved the same parties, illustrate the factors that courts may consider. The matter was a post-divorce dispute regarding which parent was to have the care and protection (custody) of the two young children. The applicable law was s15 of the Matrimonial Causes Act (Cap 192) and Article 3(1) of the UNCRC. In both cases the relative merits of each parent were considered. The first case, ${ }^{46}$ however, was essentially a parent-centred decision. The views of the young children were not heard. ${ }^{47} \mathrm{~A}$ welfare approach was adopted rather than a child's best interests. The order to split the children, awarding custody of the son to the father, who was planning to move to Papua New Guinea, and that of the daughter to the mother, who was planning to move to Japan, was subsequently challenged by the mother, in 2018.

Heard by the Master of the Court, ${ }^{48}$ this time considerable care was taken to focus on the best interests of the children, in determining which of the parents should have custody. By now the children were slightly older (nine and six-years-old) and their views were clearly taken into account by the Master, who decided to award custody of both children to the mother. In

\footnotetext{
${ }^{46}$ Justice Aru presiding (Papua New Guinea).

47 The children were four-years old and seven-years old. They were represented by a lawyer from the Public Solicitor's Office.

${ }^{48}$ Cybelle Cenac, Master (Caribbean).
} 
doing this the court was assisted by the fact that the mother had obtained a psychological assessment of the children and six reports presented to the court pertained solely to the children. The court itself had also been proactive, ordering visits to the homes of both parents to determine which was best able to provide for the children and commissioning their own psychologist to interview the children. The court had also interviewed and observed the children on two occasions.

In reaching a decision, the court referred extensively to the UNCRC and also to UK legislation, notably the Children Act 1989. This post-dates the Guardianship of Minors Act 1971, which is the Act which applies in Vanuatu. In referencing the Children Act the Master adopted a substantive child rights approach stating that the court should consider:

a) The ascertainable wishes and feelings of the child concerned (considered in the light of his age and understanding);

(b) His physical, emotional and educational needs;

(c) The likely effect on him of any change in his circumstances;

(d) His age, sex, background and any characteristics of his which the court considers relevant;

(e) Any harm which he has suffered or is at risk of suffering;

(f) How capable each of his parents, and any other person in relation to whom the court considers the question to be relevant is of meeting his needs. ${ }^{49}$

\footnotetext{
49 This is taken from the Paclii record of the judgment. The Children Act 1989 (UK) lists these in section 1(3). The Act uses the term 'his'.
} 
The court recognised that there is a balancing exercise involved and that while 'a child's wishes are not the most important factor, the court will certainly consider them, and in this case, the court will, in the balance, give due weight to the wishes of the children' ${ }^{50}$

The approach of the court was unusual, not only in considering post-independence legislation (the Children's Act 1989), but also in referencing guidelines found in child-focussed innovations in the region, notably The Lukautim Pikinini Act 2015 of Papua New Guinea, and scholarship on the best interest of the child. ${ }^{51}$ The court concluded, 'this case is not about parental rights but the rights of the children and the parent's responsibilities to them and how best each exercises that responsibility'. ${ }^{52}$ Here therefore, substantive effect was given to the UNCRC.

In this case the parties were not indigenous. While this in no way detracts from the significant advances to a children's rights approach made by this case, it was acknowledged that cultural considerations, in relation to close extended family ties and traditions, might lead to different outcomes. This obiter dicta highlights one of the dilemmas that may confront Pacific judges: the role of culture and local custom weighed against more contemporary ideas about children's rights. This dilemma is considered in more detail below.

\subsubsection{Adoption}

In the case of formal adoption one of the challenges is balancing the Article 3 rights of the child with Article 21 which states that inter-country adoption should be a last resort. ${ }^{53}$ A case in point is Application for Letters of Adoption for $J$ [2015] TOSC 5. Here the judge clearly

\footnotetext{
${ }^{50}$ No numbered paragraphs in this case.

${ }^{51}$ Referring to Jalal I. Law for Pacific Women 1998.

${ }^{52}$ See footnote above.

${ }^{53}$ Article 21(b).
} 
drew attention to these two conflicting Articles in a case where maternal grandparents residing in New Zealand were seeking to adopt a five-year old illegitimate Tongan boy. Although the application was refused in line with Article 21, in considering Article 3, considerable attention was given to the material advantages which the grandparents in New Zealand could offer the child.

This material interpretation of best interests is not unusual in the Pacific. Adoption and relocation to Australia and/or New Zealand is often assumed to be in the best interests of the child, but the child's right may be incidental. The adoption not only means that the relocated adoptee will get a good education and therefore a good job and be able to assist the extended family economically, but it may pave a path for further migration of family members. This is not incompatible per se with Article 3 which requires best interests to be a primary not paramount concern. but may raise issues regarding what is in the child's best interests and what is in the best interests of others.

There is, however, scope for judges to interrogate an application for inter-country adoption, although the focus may be more on Article 21 than Article 3. This was done in the Tongan case of Application for Letters of Adoption for Holani, In re [2015] TOSC $10 .^{54}$ The judge, who had taken the 16-year-old child's views into account stated: 'In my view, the purpose of this application, is not to create a genuine parent-child relationship between (the child) and the applicants and she is not in need of new parents. The purpose is to provide a means by which (the child) may reside in New Zealand and take the benefits that it is perceived New

\footnotetext{
${ }^{54}$ The case was heard by Lord Chief Justice Paulsen (New Zealand). Article 21 indirectly gives effect to the 1993 Hague Convention on the Protection of Children and Co-operation in Respect of Inter-country Adoption, to which few Pacific countries are signatories.
} 
Zealand will offer her by way of education and employment' (para 11). The application was refused. ${ }^{55}$

\section{Reconciling the UNCRC with 'informal justice mechanisms'}

UNICEF Pacific note that '[I]nformal justice mechanisms are practiced in all PICTS (Pacific Island Countries) and pose a rights risk, particularly to child victims, who may be encourage to 'reconcile' without accessing justice' (UNICEF 2017:9).

Ascertaining the extent to which a custom or traditional practice has become customary law is no easy task (Lunabeck 2004). As Corrin points out, 'One of the biggest obstacles to the effective operation of customary law within the formal legal system is the absence of a universally accepted definition' (Corrin 2002) and this is complicated further by the fluidity of custom in terms of adaptation and interpretation.

When cases coming before the formal courts raise matters of custom however, the relationship between 'western' law and 'custom' has to be addressed. The most significant of these practices to this article are traditional payments of compensation and customary apologies in the context of criminal law cases.

\subsection{Compensation}

Customary compensation may be paid prior to any court hearing or may be ordered to be paid by the court. It is the former which is of most concern. While such payment is seen as evidence of remorse and intended to restore harmony within the community (Paterson 2006), there are two possible UNCRC consequences. First, it may also divert the court's attention from a child victim, particularly girl children who have been subject to rape and/or sexual

\footnotetext{
${ }^{55}$ See similarly, Application for Letters of Adoption for J, in re [2015] TOSC 5, but compare the case of Leger v Solicitor General [2016] TOCA 11.
} 
abuse, rendering that child invisible or incidental to the case. Secondly, the payment is taken into account by the court in mitigation of sentence. An illustrative case is that of State $v$ Patapata [2016] PGNC 224, ${ }^{56}$ involving the statutory rape of a child by her paternal grandfather. The accused's only defence was that he had paid considerable customary compensation to the victim's family and a further cash sum was promised to the child. ${ }^{57}$ This, together with age of the accused resulted in a suspended sentence of eleven years. ${ }^{58}$ The sole reference to the UNCRC was that Papua New Guinea had met its obligations by increasing penalties for sexual offences against children through legislative amendment to the Criminal Code. The child's rights were invisible.

\subsection{Apology}

Besides customary compensation payments, traditional or customary forms of apology and reconciliation are also recognised by the courts. In Fiji this is the practice of Bulubulu and in Samoa i'Foga.

In Fiji Bulubulu, has been described as playing 'a crucial role in the families (of victim and defendant) in sweeping the sex offence complaints under the carpet' ${ }^{59}$ The practice has been criticised by the Committee on the Rights of the Child and in commentary in the Pacific

\footnotetext{
${ }^{56}$ Justice Toliken.

57 This was listed in para 13.

${ }^{58}$ Compare however, the comments in State v Kulap [2019] PGNC 179 [6] 'It could ... send mix [sic] or wrong signals or messages out to the community at large that for serious sexual offences against children, that one can get away with a lighter sentence by paying compensation' per Justice Anis.

${ }^{59}$ State v Jone Bebe [2019] FJHC 1064 (para 9). Judge Aruna Aluthge.
} 
Human Rights Law Digest (Jalal, 2008), but nevertheless persists. ${ }^{60}$ Where it is carried out there is a strong probability that the matter will not be heard by a court, and even less likelihood that there will be an appeal to a higher court. ${ }^{61}$ Moreover, bulubulu tends to sideline the individual victim in favour of restoring harmony at village, community or interfamily level (Newland 2016). Indeed, the focus on the collective rather than the individual victim or offender may mean that no measures are taken to rehabilitate either (Roffee and Whitehead 2016), contrary to the Article 39 rights of both.

Consideration of individuals and individual rights are not however, the purpose here. In Samoa, for example, the ifoga is practised to show remorse and effect reconciliation between the families. This was considered in the case of Police v L.S. [2017] WSSC 96. ${ }^{62}$ The charge was one of manslaughter following an altercation with a friend over a mobile phone. Ifoga by the accused's family had been performed and accepted by the victim's family and reconciliation between the families had taken place. The accused's family had also assisted with the funeral of the deceased - an established custom. In this case and many others involving juvenile offenders, consideration of traditional apology linked with considerations

\footnotetext{
${ }^{60}$ See e.g. State v Tokatokavua - Sentence [2015] FJHC which involved the rape of a 9-yearold boy: bulubulu was one of several factors taken into account in mitigation.

${ }^{61}$ No Supreme Court or Court of Appeal cases where bulubulu was mentioned in conjunction with children were found.

${ }^{62}$ Justice Mata Keli Tuatagaloa (Samoan).
} 
of Articles 37 and 40, led the judge to considerably reduce sentence, ordering two years supervision, rather than imprisonment. ${ }^{63}$

Where the victim is deceased and compliance with Article 39 UNCRC encourages measures to reintegrate an offender into society, customary reconciliation and apology can have an important role to play. Where the victim has to live with the trauma however, his or her rights may be marginalised by these practices. For example, in Police v Wright [2015] WSSC $118,{ }^{64}$ ifoga had also taken place. The defendant - a 27-year-old teacher, had compelled a 16-year-old pupil to have sexual intercourse with him. While the court noted the seriousness of the abuse of trust and recorded the impact on the victim (para 14), in considering sentence the judge held: 'importantly you have apologised to the victim and her family through the ifoga process' (para 20). Sentence was reduced to three months in prison. The relevance of the UNCRC for the victim was incidental. As far as the judge was concerned the state had met its obligations by passing legislation to criminalise the conduct complained of (para 16). There was no recognition the judge had Article 3 obligations.

These customary practices play a significant role in the court process. One way of reconciling the potential conflict with expectations under the UCRC can be addressed by recognising the value of these practices while warning against the misuse of them. The Fijian case of Roligalevu v State [2012] FJHC 1092, provides an example. Justice Goundar had this to say about customary apology: 'In our country, we take pride in our customs and traditions. Customs and traditions should never be used to restrict access to justice. If anything, customs

${ }^{63}$ See similarly, in Tonga, Rex $v$ Afeaki [2020] TOSC 4, in which an apology had been given and accepted by the victim of indecent assault by a juvenile. This, together with consideration of the UNCRC and a guilty plea led to a suspended sentence.

${ }^{64}$ Justice EM Aitken (New Zealand). 
and traditions should be a medium to correct the harm done to the victim by making the offender accountable. Without accountability, relationships cannot be restored, no matter how much traditional apology is offered'. In respect of the accused he said: 'The subsequent attempt to deflect your prosecution by using customs and traditions further aggravating your offending. Rather than you being remorse (sic) for your offending, you further victimized her by making her offer a traditional apology to you' (para 9). As a lower court decision this does not set a precedent but it does suggest an approach which might be adopted, particularly in trying to balance the expectations of the UNCRC with the cultural context in which judges are operating.

\section{Drawing Conclusions from Judicial Interventions}

Table Two indicates than in just under half the cases identified the UNCRC was referred to in a general way and no specific articles were identified. This suggests that the advancement of children's rights may still be in a relatively early stage. While Stalford et al, propose five possible judicial approaches, ${ }^{65}$ it is suggested that two of these are of most immediate relevance to judges in Pacific islands. These are: '(i) drawing on and utilising to maximum effect the formal legal tools which give effect to children's rights' and (iii) endorsing 'child-

${ }^{65}$ These are: (i) the utilisation to maximum effect of formal legal tools including the CRC; (ii) the use of scholarship to inform key concepts, tensions and presumptions; (iii) the endorsement of child-friendly procedures to maximise children's participation in legal processes; (iv) the centralisation of the child's voice and experience in the narrative of the judgment; and (v) the communication of the judgment in a child-friendly way (Stalford 2017, $85-86)$. 
friendly procedures' (2017: 53). Arguably, both of these are within the powers of Pacific judges to adopt and indeed there is already evidence that they are doing so. For example, in some cases where children are defendants there is clearly engagement with contemporary thinking about the criminal capacity of children; the need for procedural safeguards in line with Articles 37 and 40; and how children in trouble with the law can be dealt with in a manner appropriate to their age, using the discretions conferred by sentencing guidelines. There is also evidence of judges using formal legal tools such as constitutions and rules of interpretation to advance children's rights. It is also evident, both through legislation and the dicta of judges that the responsibilities under Articles 19 and 34 are being taken increasingly seriously.

At the same time however, there are challenges confronting a children's rights approach. In particular judges do not always appear to adopt as their starting point the obligations imposed on them by Article 3(1) (mentioned above).

It is also clear that contrary to Tobin's 'whole of CRC' approach, a number of Articles are rarely considered, for example, Article 12 (2) and Article 39. The idea of children as 'rightsbearers' also presents challenges. This may be because human rights in generally are a relatively novel concept in the region (Farran 2010), or because Pacific society tends to focus on the family, the clan or community - as illustrated by the role of traditional apology, customary compensation and the considerations taken into account in adoption cases. For these reasons it is suggested that adopting Stalford's steps ii, iv and v, might be too ambitious at present, although it would be interesting to hear the views of Pacific judges on this.

In respect of steps (i) and (iii) however, there is already evidence that there are possible avenues for advancing children's rights. One way is to draw on common values between the 
UNCRC and the traditional and Christian values that are integral to most Pacific societies. ${ }^{66}$ It may also be the case that there are regional or national developments that provide a more enabling environment for judges to focus on children's rights, for example NGO and INGO reports, recent legislation, ${ }^{67}$ law reform proposals, aid funded judicial training initiatives, and the recommendations made through the various $\mathrm{UN}$ reporting processes.

There are, however, be basic resource constraints. These can include lack of access to expert evidence to establish, for example, the psychological trauma an event has caused a child or a pre-sentencing assessment to determine any issues that have affected a particular childaccused. There may also be court-room practices that are deeply entrenched, for example, the cross-examination of child witnesses, including victims, in open court. There may also be a lack of differential development of legal concepts such as consent, duress and undue influence in relation to children, or statutory requirements for corroboration in sexual assault cases. Similarly, judges may lack access to scholarship on children's rights and how judges can advance these.

Some of these issues cannot be changed by judicial engagement with children's rights, but others can. For example, where rules of interpretation, the constitution or established judicial precedent allows a judge to refer to international law, then the UNCRC can be called on to provide an appropriate child's rights' perspective. Where the law rests on common law principles, comparative approaches can be used to see how these can be applied in cases involving children. Where there are practice guidelines judges can determine what weight

\footnotetext{
${ }^{66}$ See the Samoan case of Police v JI above.

${ }^{67}$ See e.g. the reference to Lukautim Pikinini Act 2015 of Papua New Guinea, in the Vanuatu case of Nakamura $v$ Dalley [2018]VUSC 134.
} 
should be given to different criteria, or, if these are established by the highest courts, change these.

It is true that in these jurisdictions the judiciary is numerically small and may be overstretched. The Children's Rights' judgment project demonstrated, however, that despite geographical distance, different court structures, and different cultures, it was possible to adopt a child-rights approach. In the Pacific, high court judges are not totally isolated. There are opportunities for them to share and exchange best practice, for example, through the Pacific Islands Legal Officers Network, and the Commonwealth Magistrates' and Judges' Association. Existing initiatives could be utilised such as the Pacific Judicial Strengthening Initiative which was launched in 2016. This has produced a number of toolkits for Pacific judges and future toolkits could build on the positive UNCRC approaches being developed by judges in the region. Such toolkits could also provide an opportunity for working with Pacific judges to co-create solutions that work for the Pacific. This could even include working with young people.

At the UN Child Rights Committee meeting referred to at the outset of this article, Committee members met Pacific children. While the Committee did not focus on the importance of the UNCRC in the context of legal proceedings, it did acknowledge that the contributions and views of children are a 'valuable and necessary part of our work' (UNICEF 2020). Perhaps it is time for judges in the region, to consider how they, too, can develop a more child-orientated administration of justice by sharing experiences, recognising best practice and hearing children's voices.

\section{References}


Baird, N. 'Judges as cultural outsiders: Exploring the model of judging in the Pacific' Canterbury Law Review 2014 (19) 80-96

Baird, N. 'The universal periodic review: Building a bridge between the Pacific and Geneva' in H. Charlesworth and E. Larkin (eds) Human Rights and the Universal Periodic Review: Rituals and Ritualism (Cambridge, Cambridge University Press 2015) 187-212

Brown, K. and Corrin Care, J. 'Conflict in Melanesia: Customary law and the rights of women’ Commonwealth Law Bulletin 1998 (24, 3-4) 1334-1355

Corrin Care, J. 'Wisdom and worthy customs: Customary law in the South Pacific ALRCRefJ1 2002 (20) 31-36 and 72

Corrin, J. 'Moving beyond the hierarchical approach to legal pluralism in the south Pacific' Journal of Legal Pluralism 2009 (59) 29-49

Corrin, J., 'The rights of the child in Solomon Islands' plural legal system' in O. Cvejić Jančić (ed.), The Rights of the Child in a Changing World, Ius Comparatum - Global Studies in Comparative Law 13, (Springer International Publishing, Switzerland 2016) 263-292

Dale, G., 'Appealing to Whom? Australia's “Appellate Jurisdiction” over Nauru' The International and Comparative Law Quarterly 2007 (56, 3) 641-658

Dziedzic, A., 'Foreign judges on Pacific courts: Implications for a Reflective Judiciary' Federalismi (Special Issue 5) 2018, 63

Farran, S. 'Children of the Pacific: Giving effect to Article 3 UNCRC in small island states' The International Journal of Children's Rights $2012(20,2)$ 199-223 
Farran, S. Human Rights in the South Pacific: Challenges and Changes (Abingdon, Routledge 2010)

Ingram, C. 'The Length of Terms of Judges in the Pacific and its Impact on Judicial Independence' in Land Law and Judicial Governance in the South Pacific: Comparative Studies Special Issue Volume XII, (Wellington, University of Victoria, Faculty of Law, 2011) 375-383

Jalal, I. and Madraiwiwi, J. (eds) Pacific Human Rights Digest, Volume 2 (Suva, Secretariat of the Pacific Community, 2008)

Jessop, O. 'Customary Family Law and Gender Discrimination in Papua New Guinea' in T. Newton Cain and A. Jowitt (eds) Passage of Change: Law Society and Governance in the Pacific (Canberra, ANU Press, 2010) 215-230

Jowitt, A. 'Sentencing for Sexual Offences: A comment on Wenu v Public Prosecutor [2015] VUCA 51' Journal of South Pacific Law 2015 (10)

Lunabeck, V. 'Adjudication of Customary Law in the Pacific' Commonwealth Judicial Journal 2004 (15) 25-35

Newland, L. 'Villages, Violence and Atonement in Fiji' in Biersack, A (ed) Gender Violence and Human Rights: Seeking Justice in Fiji, Papua New Guinea and Vanuatu (Canberra, ANU Press, 2016) 47-79 
Pacific Judicial Strengthening Initiative, Human Rights Toolkit October 2017, Federal Court of Australia and New Zealand Foreign Affairs and Trade Aid Programme https://www.fedcourt.gov.au/pjsi/resources/toolkits/Human-Rights-Toolkit.pdf

Paterson, D. 'Legal challenges for small jurisdictions in relation to privacy, freedom of information and access to justice' Journal of South Pacific Law $2009(13,1)$ available at http://www.paclii.org/journals/fJSPL/vol04/4.shtml

Paterson, D. 'Customary Reconciliation in Sentencing for Sexual Offences: A Review of Public Prosecutor v Ben and Others and Public Prosecutor v Tarilingi and Gamma' Journal of South Pacific Law 2006 (10. 1)

Powles, G. 'Common law at bay? The scope and status of customary law regimes in the Pacific' Journal of Pacific Studies 1997 (21) 61-82

Pulea, M. 'A Regional Court of Appeal for the Pacific' Pacific Perspective 1980 (9,2) 1.

Roffee, J, and Whitehead, J. 'Child Sexual Abuse in Fiji: Authority, Risk Factors and Responses' Current Issues in Criminal Justice 2016 (27,3) 323-334

Stalford, H., Hollingsworth, K. and Gilmore, S. (eds) Rewriting Children's Rights: From Academic Vision to New Practice (Oxford, Hart 2017)

Tamata, L. 'Application of Human Rights Conventions in the Pacific Islands Courts' Journal of South Pacific Law 2009 (13, 1) available at http://www.paclii.org/journals/fJSPL/vol04/12.shtml

Tobin, J., 'Judging the Judges: Are they adopting the rights approach in matters involving children’ Melbourne University Law Review 2009 (33, 2) 579-625

UNICEF 'Child rights in the Pacific: UN body concludes historic session in Samoa' 6 March 2020 
https://www.unicef.org/eap/press-releases/child-rights-pacific-un-body-concludes-historicsession-samoa last accessed 8 August 2020

UNICEF 'Situation Analysis of Children in the Pacific island Countries' (UNICEF, Pacific Office Suva, 2017) https://www.unicef.org/pacificislands/reports/situation-analysis-childrenpacific-island-countries 